\title{
Studies on the phytoplankton of the deep subalpine Lake Iseo
}

\author{
Letizia GARIBALDI*, Antonella ANZANI, Alessandro MARIENI, Barbara LEONI ${ }^{1)}$ and Rosario MOSELLO ${ }^{2)}$ \\ Dip. Scienze dell'Ambiente e Territorio Università degli Studi di Milano Bicocca, P.zza della Scienza 1, 20126 Milano, Italy \\ ${ }^{1)}$ Dipartimento di Biologia, Università degli Studi di Milano, Via Celoria 26, 20133 Milano, Italy \\ ${ }^{2)}$ CNR Istituto per lo Studio degli Ecosistemi, Largo Tonolli 50, 28922 Verbania Pallanza, Italy \\ *e-mail corresponding author: letizia.garibaldi@unimib.it
}

\begin{abstract}
This paper reports the results of investigations carried out on the chemical characteristics and phytoplankton community of Lake Iseo. Samplings were performed on a monthly basis from 1998 to 2000. At least three main algal groups dominated the community throughout the study period. The large Bacillariophyceae were dominant mainly during late winter and early spring (Aulacoseira spp., Melosira varians, Asterionella formosa), with few species able to maintain occasional positive growth also during mid summer and/or autumn (Fragilaria crotonensis and Diatoma elongatum). The thermal stability of the water column and silica depletion were the main factors responsible for the decline of the large spring diatoms. The subsequent growth of Mougeotia sp. (Conjugatophyceae) was favoured by its lower sinking rate and resistance to increasing grazing pressure by the dominant copepods (Copidodiaptomus steueri) and cladocerans (Daphnia hyalina $x$ galeata). Among the cyanobacteria, the greater development of Planktothrix rubescens in the autumn months, with conditions of vertical homogenisation and decreasing $Z_{e u} / Z_{\text {mix }}$ ratios, was favoured by its ability to survive at low light irradiances. The temporal replacement of these three groups constitutes the main sequence of the annual phytoplankton succession in Lake Iseo. A large development of other algal groups was recorded only in one or two of the three study years (e.g. Dinophyceae and Chlorococcales). The changes observed in the annual phytoplankton development are discussed in the light of differences in the spring fertilisation of the waters, caused by differences in the depth of the layer involved in the late winter and spring vertical mixing.
\end{abstract}

Key words: phytoplankton, deep subalpine lakes, Lake Iseo

\section{INTRODUCTION}

The deep southern subalpine lakes, or Insubrian lakes (from West to East, Orta, Maggiore, Lugano, Como, Iseo, Idro and Garda), are located in one of the most densely populated and highly productive areas of Italy. They are an important resource for agriculture, industry, fishery and drinking water, as well as for recreation and tourism, thanks to the beauty of their natural setting and their water quality. The total volume of these lakes $\left(122.7 \mathrm{~km}^{3}\right)$ constitutes around $82 \%$ of Italian lacustrine resources, estimated at around $150 \mathrm{~km}^{3}$.

During the 1960s, intensifying eutrophication processes and the corresponding deterioration of water quality in northern Italy were becoming apparent, initially in lakes with low maximum depths (Lake Varese and Lake Endine), and subsequently in the deep subalpine lakes. This situation prompted a series of investigations to assess the human impact on the trophic and hydrochemical evolution of the Insubrian lakes over the last 30 years. The limnological investigations carried out during the 1990s resulted in an update of the trophic evolution of the largest lakes (Mosello \& Giussani 1997). At present Lago Maggiore is close to its original pristine oligotrophic conditions; Lake Garda oscillates between oligotrophy and mesotrophy; Lake Como shows conditions between mesotrophy and eutrophy; and lakes Iseo and Lugano are eutrophic.
Past studies on Lake Iseo were described in Garibaldi et al. (1997b). The increase of algal nutrient loads has resulted in a dramatic worsening of the trophic conditions of the lake. Reactive phosphorus in the whole water column increased from around $10 \mu \mathrm{g} \mathrm{P}^{-1}$ in 1967 , to 20,32 and $50 \mu \mathrm{g} \mathrm{P} \mathrm{l}^{-1}$ in 1973,1980 and 1990, respectively (Garibaldi et al. 1998). The last mixing involving the deepest waters in Lake Iseo occurred at the beginning of the 1980s; during the second half of the 1980s, there was a marked decrease in hypolimnetic oxygen concentrations and the establishment of conditions of anoxia during the 1990s (Garibaldi et al. 1995, 1999). In fact, owing to climatic factors (mild winters) and to the accumulation of calcium and bicarbonate ions in the hypolimnion, Lake Iseo may currently be defined as meromictic. Lake Lugano (Barbieri \& Simona 1997) and Lake Idro (Garibaldi et al. 1997a) have also been in this state since the 1950 s and the 1960s, respectively. Under these conditions the renewal time of the deepest waters is reduced, favouring the increase of nutrients (due to internal recycling) and further increasing water density (due to the dissolution of $\mathrm{CaCO}_{3}$ ). These changes have a huge impact on water usability, particularly for fishing, drinking and recreational purposes.

The increase in nutrient concentrations was paralleled by a corresponding increase in algal biomass. Among the cyanobacteria, Planktothrix rubescens, which was observed for the first time during the 1970s, 


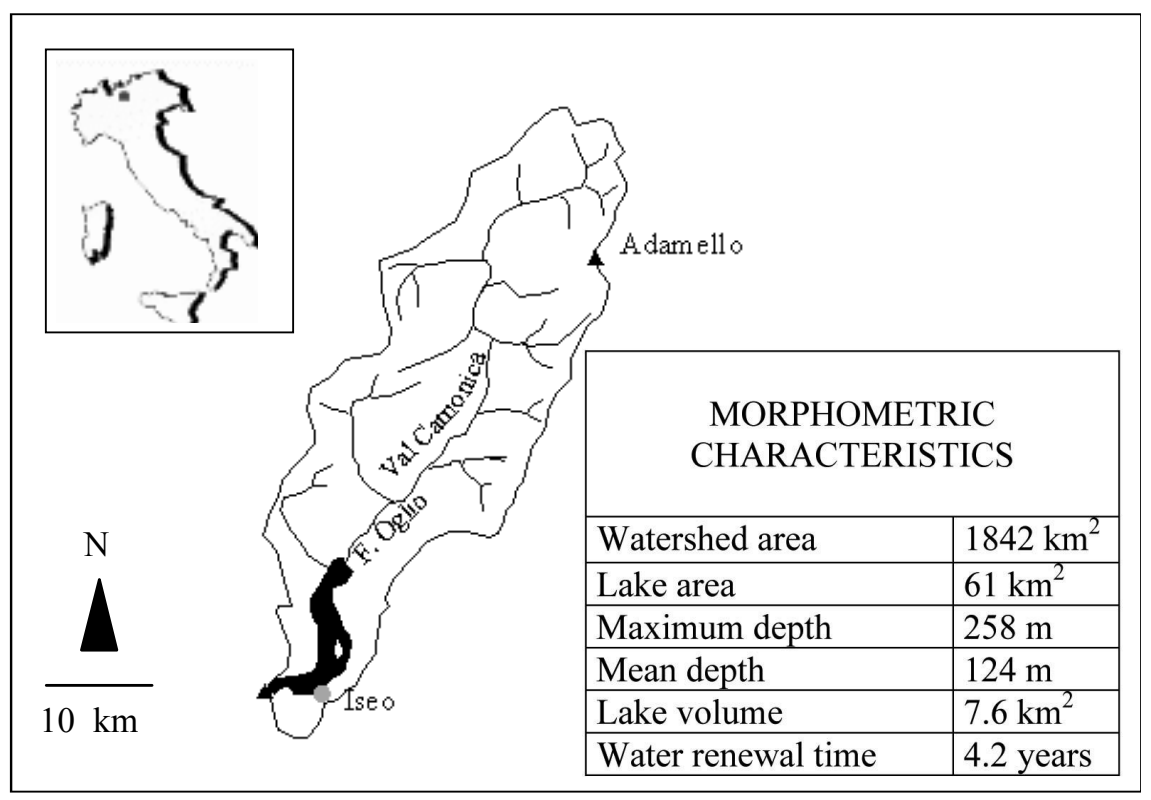

Fig. 1. Lake Iseo and its drainage basin: the main morphometric characteristics are reported.

has shown striking increases over the last 20 years, and now represents one of the most abundant phytoplankton species of Lake Iseo. In addition, extensive surface water blooms of Anabaena lemmermannii have been observed since the 1990s, particularly along the shore.

This study is aimed primarily at evaluating the recent structure and dynamics of phytoplankton in Lake Iseo. The general lines of research were elaborated according to a common protocol, in the framework of a project on the trophic evolution of the deep Insubrian lakes (Mosello \& Salmaso 2000; Ruggiu 2002).

\section{STUDY AREA}

With a surface of $61.8 \mathrm{~km}^{2}$ and a volume of $7.5 \mathrm{~km}^{3}$, Lake Iseo (also known as Sebino) is the fourth largest Italian lake, after Garda, Maggiore and Como. It lies in the foothills of the Alps, at the end of a prealpine valley (Val Camonica). The inflow and outflow is the River Oglio, which forms the border between the provinces of Bergamo and Brescia. At the centre of the lake is the island of Monte Isola, which is the largest $\left(4 \mathrm{~km}^{2}\right)$ and highest (414 $\mathrm{m}$ above the lake surface) lacustrine island in Europe. The islets of Loreto and S. Paolo lie respectively off the northern and southern shores of the island. The surface area of the watershed, including the lake, is $1842 \mathrm{~km}^{2}$, with a highest point of $3554 \mathrm{~m}$ a.s.l. and a mean altitude of $1429 \mathrm{~m}$. The theoretical renewal time of the lake is about 4.2 years (Garibaldi et al. 1999). The main characteristics of Lake Iseo and its watershed are reported in figure 1.

Water temperatures in the deep Insubrian lakes do not drop below $4{ }^{\circ} \mathrm{C}$, so that, according to Hutchinson (1957), they should be classified as "warm monomictic". In this type of lakes full circulation of the water column should occur every year, during or at the end of the winter. However, owing to their great depth, these lakes tend to circulate only irregularly, during harsh, windy winters. At present only the largest lakes (Garda, Maggiore and Como, which may be classified as holooligomictic) share this characteristic, whereas lakes Lugano, Idro and Iseo are meromictic.

\section{METHODS}

\subsection{Chemical and physical parameters}

Sampling was performed at a station located between Montisola and the western shore, in a central position close to the site of maximum depth, about $258 \mathrm{~m}$. Samples for chemical analysis were taken monthly; the water was collected using Van Dorn bottles (3.5-1 volume) at the following depths: $0 \mathrm{~m}, 1 \mathrm{~m}, 10 \mathrm{~m}, 20 \mathrm{~m}, 30$ $\mathrm{m}, 50 \mathrm{~m}, 75 \mathrm{~m}, 100 \mathrm{~m}, 150 \mathrm{~m}, 200 \mathrm{~m}, 245 \mathrm{~m}$. The samples were transferred to the laboratory for immediate analysis.

Secchi disk depth, temperature and dissolved oxygen were measured in situ. The euphotic depths $\left(\mathrm{Z}_{\mathrm{eu}}\right)$ were estimated from Secchi disk readings using the relationships reported in Salmaso (2002). Temperature and oxygen concentration were determined with an automatic oxygen sensor coupled with a thermistor probe (Microprocessor Oximeter WTW OXI 320). The oxygen concentrations were occasionally checked in the laboratory by Winkler titration (APHA 1985).

The following parameters were measured in the laboratory: $\mathrm{pH}$ ( $\mathrm{pH}$ meter Radiometer PHM 83), conductivity (conductimeter Radiometer CDM 83), total phosphorus (Valderrama 1981), nitrate nitrogen (Rodier 1984), silica (APHA 1985) and chlorophyll- $a$ (Lorenzen 1967). 


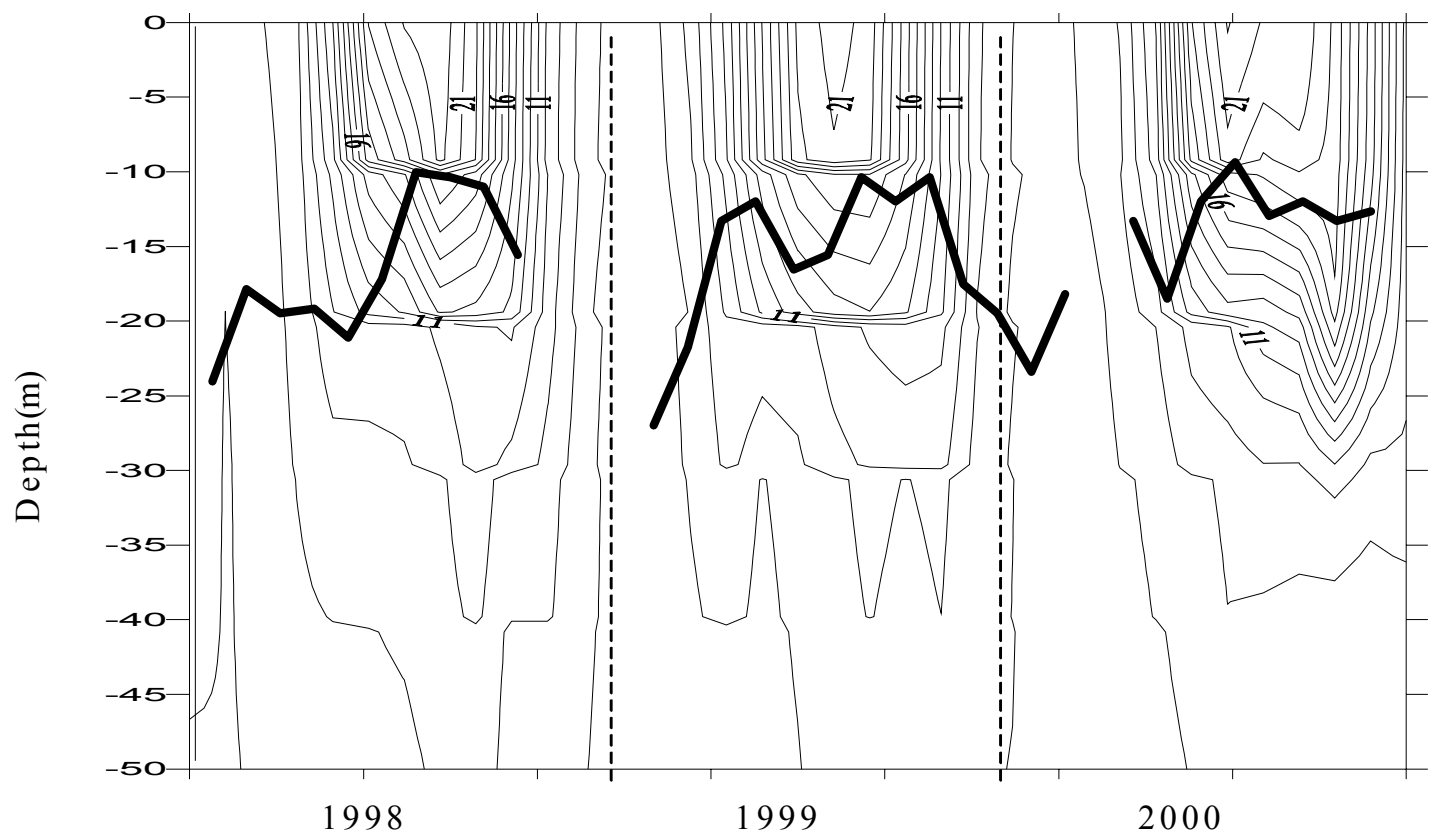

Fig. 2. Isopleths of temperatures $\left({ }^{\circ} \mathrm{C}\right)$ with superimposed seasonal variations of the euphotic depth $(\mathrm{m})$.

\subsection{Phytoplankton}

Samples for phytoplankton analysis were collected monthly at six depths in the 0-10 m layer. Equal volumes of each discrete sample were then mixed to obtain an integrated sample representative of the 0-10 m layer, subsequently used for counting. Samples were fixed with acetic Lugol's solution. The organisms were counted by the inverted microscope method. The identification keys reported in Bourelly (1966, 1968, 1970) and Huber-Pestalozzi (1938, 1942, 1955, 1962, 1968, 1972 , 1982, 1983) were used to identify the algae, mostly to species level. At least 200 individuals of the most abundant species were counted, with a counting error of about $15 \%$ (Lund et al. 1958). The cell volume for each species was estimated according to Rott (1981).

\subsection{Zooplankton}

Zooplankton were sampled using two small nets of $40 \mathrm{~cm}$ diameter. The mesh size was $200 \mu \mathrm{m}$ for collecting Copepoda and Cladocera, $50 \mu \mathrm{m}$ for Rotifers and the young stages of Copepoda.

Sampling was performed along a vertical gradient to a depth of $10 \mathrm{~m}$; three samples were taken at each point along the vertical, and the filtered material was mixed and preserved in $4 \%$ formalin. The taxa present in the lake were identified and counted with an optical microscope; most of the animals were identified to species level. The following manuals were used for the classification: Dussart (1969), Ruttner-Kolisko (1974), Braioni \& Gelmini (1983), Margaritora (1983), Amoroso (1984), Reddy (1994) and Einsle (1996).

\section{RESULTS}

\subsection{Temperature and thickness of the euphotic zone}

Homothermy, with temperatures around $6.5^{\circ} \mathrm{C}$ on the whole water column, was reached in February 1999 and 2000. In contrast, in 1998 the temperature at the surface never fell below $7.2^{\circ} \mathrm{C}$. A detailed analysis of the chemical and physical profiles leads to the assumption that the 1999 and 2000 mixings in Iseo reached a depth between 100 and $200 \mathrm{~m}$, much deeper than the 1998 mixing, which involved a depth between 50 and $100 \mathrm{~m}$.

The progressive thermal stratification begins in spring and becomes well-defined from June to August, with the thermocline at a depth between 10 and $20 \mathrm{~m}$ (Fig. 2).

During the maximum summer stratification, the minimum thickness of the euphotic zone is reduced to around $10 \mathrm{~m}$, while during the winter months values may be close to $30 \mathrm{~m}$ (Fig. 2).

\subsection{Dissolved oxygen, $p H$ and conductivity}

In the surface layer $(0-10 \mathrm{~m}), \mathrm{O}_{2}$ concentrations are always higher than $9.0 \mathrm{mg} \mathrm{l}^{-1}$. In the $0-10 \mathrm{~m}$ layer from April to October, oxygen oversaturation is present, due to intense algal photosynthetic activity (Fig. 3A). The highest percent saturation at single depth was $162 \%$, recorded at $10 \mathrm{~m}$ in July 2000.

In the top $10 \mathrm{~m}, \mathrm{pH}$ values are constantly higher than 8.5 from late spring to the beginning of the autumn. Maximum $\mathrm{pH}$ values (around 9.0) were measured in 


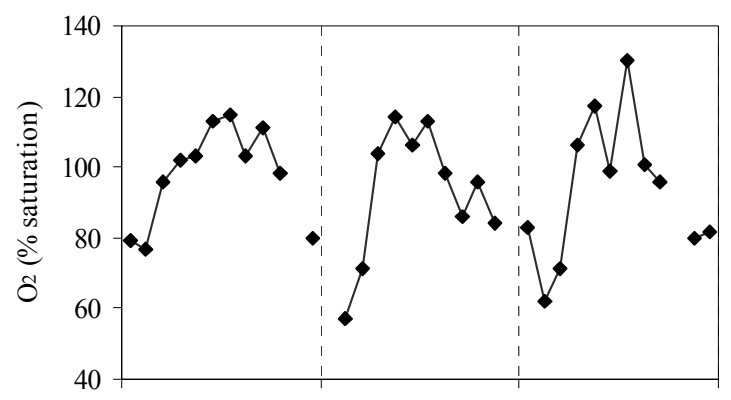

A

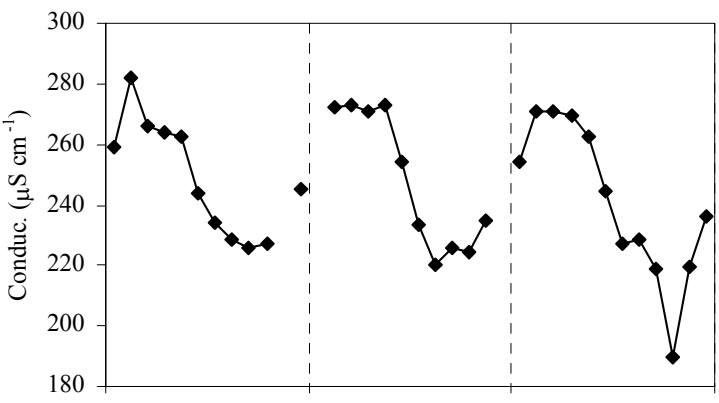

C

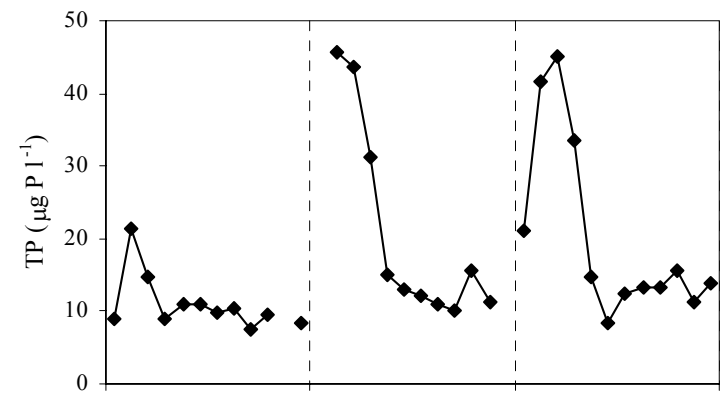

$\mathbf{E}$

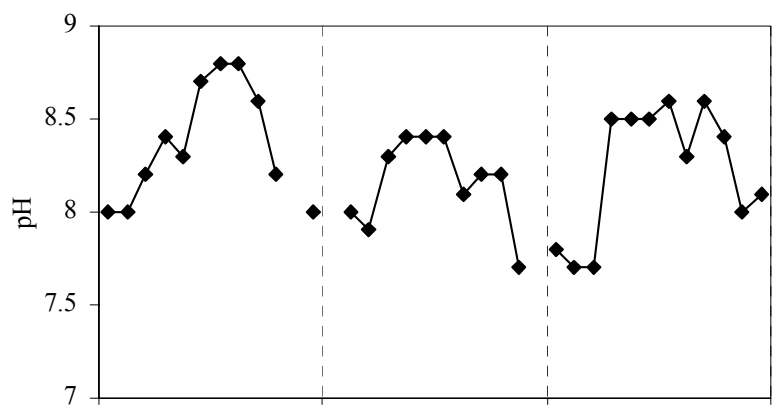

B

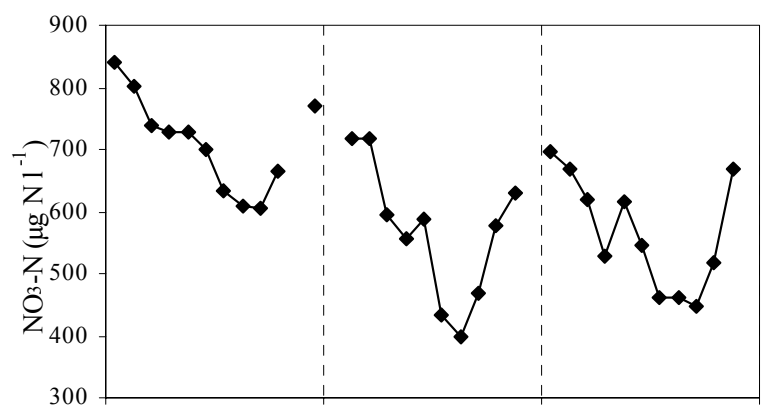

D

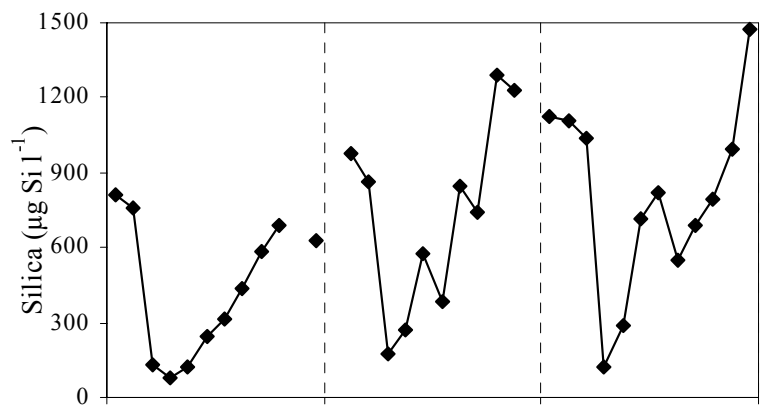

$\mathbf{F}$

Fig. 3. Temporal variations of (A) oxygen (percent saturation), (B) $\mathrm{pH},(\mathbf{C})$ conductivity, (D) nitrate nitrogen, (E) total phosphorus and $(\mathbf{F})$ reactive silica in the $0-10 \mathrm{~m}$ layer.

August 1998 in correspondence with high concentrations of chlorophyll- $a$ (Fig. 3B; see section 4.5).

Due to their common dependence on photosynthetic processes, dissolved $\mathrm{O}_{2}$ (in percentage) and $\mathrm{pH}$ showed a close linear correlation $(r=0.83, P<0.01)$. Furthermore, $\mathrm{O}_{2}$ exhibits a close correlation with phytoplankyon biomass, measured both in terms of chlorophyll- $a(r=0.38, P<0.05)$ and in terms of total biovolume $(r=0.56, P<0.01)$. A similar relationship was also observed between total biovolume and $\mathrm{pH}(r=$ 0.34, $P \sim 0.05$ ).

Similarly to $\mathrm{O}_{2}$ and $\mathrm{pH}$, conductivity in the euphotic zone followed a marked seasonal trend, with maximum values in winter (between 260 and $280 \mu \mathrm{S} \mathrm{cm}^{-1}$ ) and minima in summer (between $220-226 \mu \mathrm{S} \mathrm{cm}^{-1}$ in 1998 and 1999, and $190 \mu \mathrm{S} \mathrm{cm}^{-1}$ in 2000). The decrease in conductivity is linked to the precipitation of calcium carbonate, which is mainly caused by algal $\mathrm{CO}_{2}$ depletion during summer stratification (Garibaldi et al. 1997a).

\subsection{Algal nutrients}

The most important form of $\mathrm{N}$ is nitrate nitrogen, the concentration of which are between 400 and $850 \mu \mathrm{g} \mathrm{N}$ $\mathrm{l}^{-1}$ in the 0-10 m layer (Fig. 3d). Ammonium nitrogen usually exhibits relatively low values, between 10 and $50 \mu \mathrm{g} \mathrm{N}^{-1}$. The summer consumption of nitrate was particularly marked in 1999, with a decrease in concentration in the $0-10 \mathrm{~m}$ layer from almost $800 \mu \mathrm{g} \mathrm{N}{ }^{-1}$ (December 1998) to $400 \mu \mathrm{g} \mathrm{N}^{-1}$ (31 August). The low- 
est $\mathrm{NO}_{3}-\mathrm{N}$ concentrations in the surface layer were again measured in 1999 (225 $\mathrm{g} \mathrm{N}^{-1}$ on 31 August).

In the three study years, total phosphorus concentrations in the top $10 \mathrm{~m}$ showed highly variable values. The maxima, which were always measured in correspondence with the greatest extent of the late winter mixing, were relatively low in $1998\left(21 \mu \mathrm{g} \mathrm{P}^{-1}\right)$ and fairly high in $1999\left(46 \mu \mathrm{g} \mathrm{P}^{-1}\right)$ and $2000\left(45 \mu \mathrm{g} \mathrm{P} \mathrm{l}^{-1}\right)$ (Fig. 3E). These differences were a consequence of the greater extent of the mixed layer in 1999 and 2000 (see 4.1.), and had major consequences on the development of algal biomass in the three years of the study (sections 4.5. and 4.7.).

Silica concentration in the top $10 \mathrm{~m}$ showed a regular development over time, characterised by a marked decrease in spring (down to $0.07 \mathrm{mg} \mathrm{Si}^{-1}$ in April 1999), followed by a gradual increase in late summer and early winter, when the highest values were usually recorded (maximum $1.5 \mathrm{mg} \mathrm{l}^{-1}$ in December 2000) (Fig. $3 \mathrm{f})$. At the surface the minimum value was measured in April 1999 (0.06 $\left.\mathrm{mg} \mathrm{Si} \mathrm{l}^{-1}\right)$.

\subsection{Zooplankton}

Zooplankton identified in Lake Iseo during 19982000 included 28 taxa (Tab. 1). Rotifera, Copepoda and Cladocera were represented by 20, 3 and 5 species, respectively. Over the thirty-four month sampling period, rotifer and crustacean zooplankton densities ranged from 2 to 362 ind $\mathrm{l}^{-1}$ and from 13 to 97 ind $\mathrm{l}^{-1}$, respectively. Rotifers dominated numerically during the warmest season (June-August), while copepoda densities were greater during spring and late summer-early autumn. Cladocera comprised less than $15 \%$ of the total zooplankton density (except in May 1999); the maximum densities in this group were attained in April-May and October-November (Fig. 4).

Rotifers were characterised by a high degree of seasonal variability. Some species, such as Keratella cochlearis, K. quadrata, Polyarthra vulgaris, Filinia longiseta and Pompholyx sulcata were present throughout the year. Others were present occasionally with different densities during the three years; in particular, Conochilus hippocrepis, which is reported separately from the other Rotifera in figure 4, showed very high density peaks in July 1998 and 1999.

Crustaceans were predominantly represented by Copepoda, with the calanoid Copidodiaptomus steueri. In general, the highest densities of this species were recorded in summer, though an exceptional peak was recorded in December 1998 (73 ind $\left.1^{-1}\right)$. The cyclopoids were represented by Mesocyclops leuckarti, in the warmest months, and Cyclops abyssorum, in winter and spring.

During 1998 Cladocera developed with lower densities than in 1999-2000. Among the Cladocera, the Daphnia hyalina-galeata complex had its maximum development in spring (e.g. 13 ind $1^{-1}$ in May 1999), whereas Diaphanosoma brachyurum was mainly present during August and September (around 8 ind $1^{-1}$ in September 2000); Bosmina (Eubosmina) longicornis was recorded with significant densities (around 17 ind $1^{-1}$ ) in different months, i.e. December 1998, May 1999 and October 2000. The two predator species, Leptodora kindtii and Bythotrephes longimanus, were represented by a few individuals only from May to October.

Tab. 1. Zooplankton taxa found from 1998 to 2000 .

\begin{tabular}{lccc}
\hline & 1998 & 1999 & 2000 \\
\hline COPEPODA & & & \\
Copidodiaptomus steueri & + & + & + \\
Mesocyclops leuckarti & + & + & + \\
Cyclops abyssorum & + & + & + \\
CLADOCERA & & & \\
Daphnia complex & + & + & + \\
Eubosmina longicornis & + & + & + \\
Diaphanosoma brachyurum & + & + & + \\
Leptodora kindtii & + & + & + \\
Bythotrephes longimanus & + & + & + \\
ROTIFERA & & & \\
Keratella cochlearis & + & + & + \\
Keratella quadrata & + & + & + \\
Kellicottia longispina & + & + & + \\
Filinia longiseta & + & + & + \\
Collotheca sp. & + & + & + \\
Collotheca mutabilis & + & & \\
Polyarthra vulgaris & + & + & + \\
Asplanchna priodonta & + & + & + \\
Synchaeta stylata & + & + & + \\
Synchaeta oblonga & + & + & + \\
Squatinella mutica & + & & + \\
Trichocerca porcellus & + & + & + \\
Trichocerca similis & + & + & + \\
Trichocerca longiseta & + & + & \\
Pompholyx sulcata & + & + & + \\
Ascomorpha ovalis & + & + & + \\
Gastropus stylifer & + & + & + \\
Conochilus hippocrepis & + & + & + \\
Euchlanis dilatata & + & + & + \\
\hline & & + \\
\hline
\end{tabular}

\subsection{Chlorophyll-a and transparency}

Chlorophyll- $a$ showed generally the highest concentrations in March and April, in correspondence with the maximum development of cyanobacteria and diatoms. A second peak of chlorophyll- $a$ occurred in mid or late summer (Fig. 5 left). In the three study years, the highest chlorophyll- $a$ concentrations were recorded in April 2000 (32 $\mathrm{g} \mathrm{g} \mathrm{l}^{-1}$ ); mean annual values in 1998, 1999 and 2000 were 5.9, 6.3 and 8.3, respectively.

The highest Secchi disk values were found from December to February, though with values never exceeding $10 \mathrm{~m}$, apart from one measurement of $11.5 \mathrm{~m}$ recorded in December 1998 (Fig. 5 right). The lowest Secchi disk value for the whole study period, $2.4 \mathrm{~m}$, was recorded in August 2000, the month which always yielded the lowest transparency values $(2.8 \mathrm{~m}$ in the two previ- 


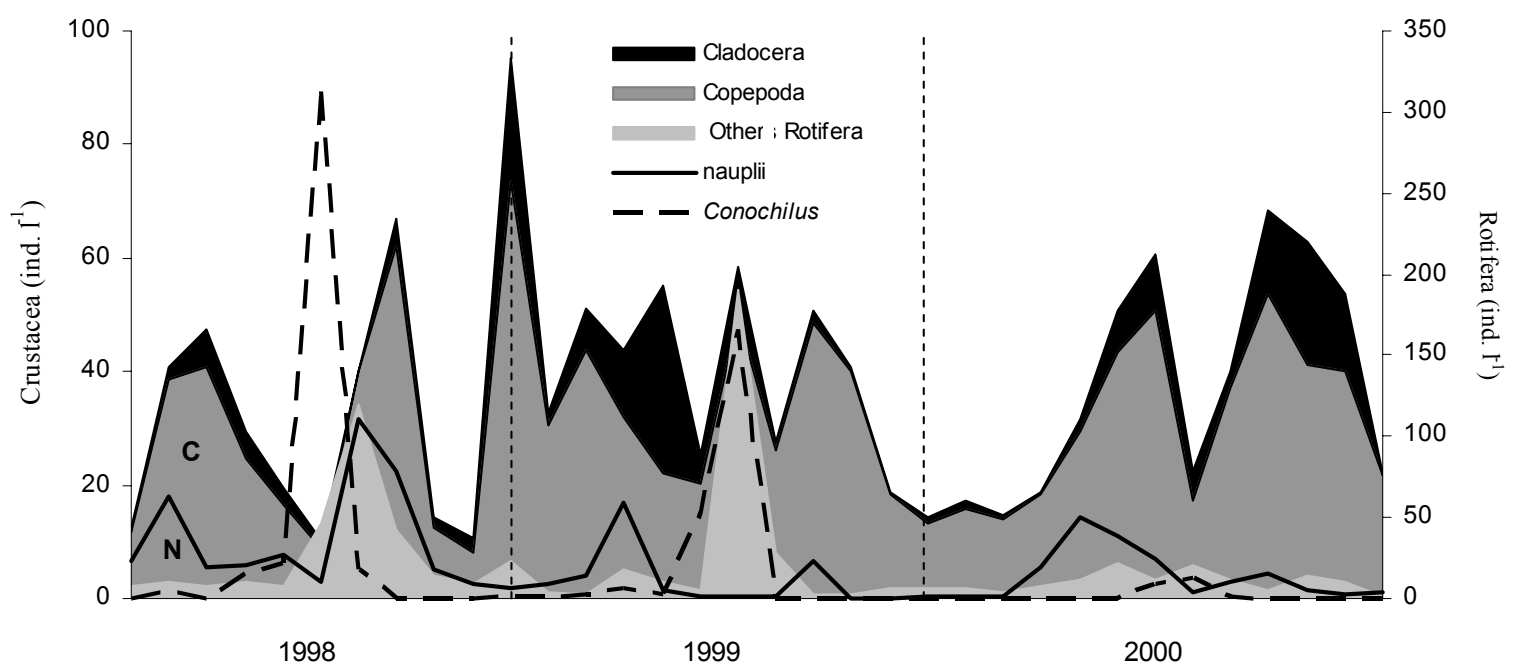

Fig. 4. Seasonal variations of the density of Copepoda, Cladocera, Conochilus and the remaining Rotifera. Among Copepoda, the contribution of nauplii ( $\mathrm{N}$ area) and copepodites and adults $(\mathrm{C}$ area $)$ is highlighted.
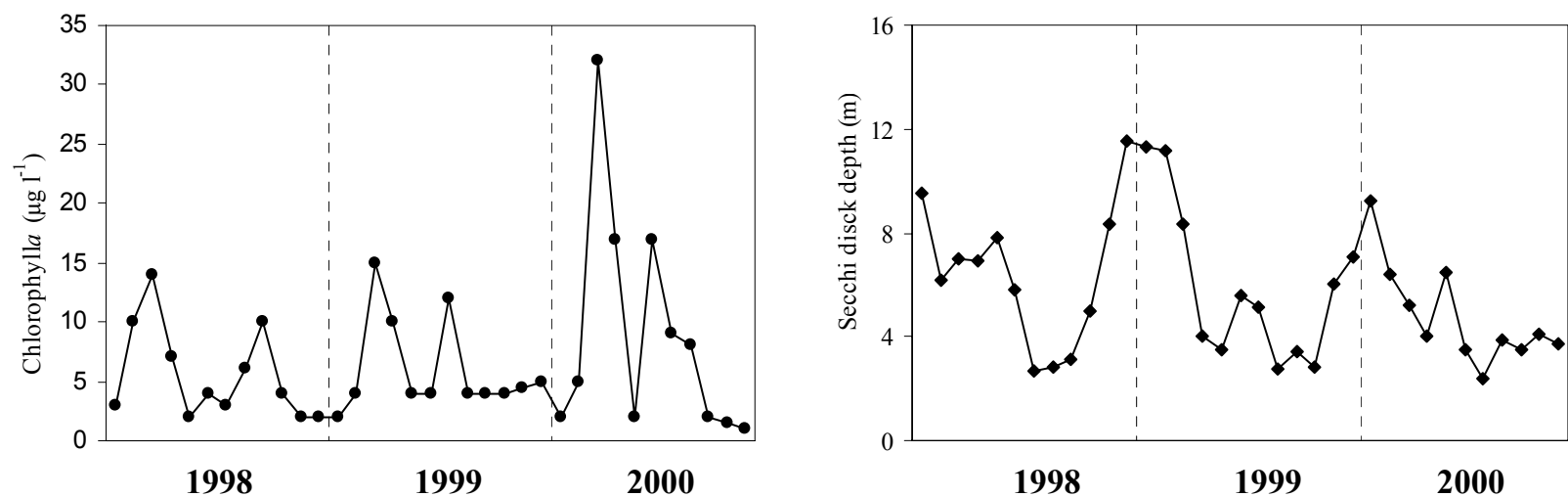

Fig. 5. Temporal variations of chlorophyll- $a$ (left) and transparency (right).

ous years). In the first two years of the study, the mean annual transparency values were very similar $(6.2 \mathrm{~m}$ in 1998 , and $6.3 \mathrm{~m}$ in 1999), falling to $4.9 \mathrm{~m}$ in 2000.

After linearisation of the two variables by log-transformation, the Secchi disk values showed a strong dependence on the seasonal trend of chlorophyll- $a\left(r^{2}=\right.$ $0.21, P=0.01)$.

\subsection{Phytoplankton density}

The highest phytoplankton density values, between 15000 and 30000 cells $\mathrm{ml}^{-1}$, were always measured from August to October, when numerous colonies of cyanobacteria developed (mainly Planktothrix rubescens and many Chroococcales, with the genera Aphanothece, Gomphosphaeria and Microcystis) (Fig. 6B). Colonial cyanobacteria reached their maximum density $(>95 \%$ of the total) in October 1999, following a large development of Planktothrix ( $\mathrm{ca} 22,000$ cells $\mathrm{ml}^{-1}$ ); the density maxima in 1998 and 2000 were caused mainly by the development of Chroococcales, as well as that of $P$. rubescens. The other groups present in high densities were Bacillariophyceae (mainly Aulacoseira islandica and $A$. granulata (in spring), Conjugatophyceae (mainly Mougeotia sp., in late spring 1999) and Chlorophyceae (mainly Chlorococcales, in summer 2000).

\subsection{Seasonal evolution of phytoplankton biovolume and dominant species}

During the three study years, 59 taxa belonging to 7 groups were identified. Of these, the best represented, as number of species were Chlorophyceae and Bacillariophyceae, each with 13 species; then came Cyanobacteria (12 species), Chrysophyceae and Conjugatophyceae (7 species), Cryptophyceae (4 species) and Dinophyceae (3 species).

Temporal variations in the biovolume of the individual algal groups - both absolute and percent - are shown in figures $6 \mathrm{~b}$ and $6 \mathrm{c}$. Taken as a whole, the temporal trend of total algal biovolumes was closely linked to that of chlorophyll- $a(r=0.63, P<0.01)$. Throughout the study period, the best represented groups in terms of biovolume were Bacillariophyceae (in late winter and 


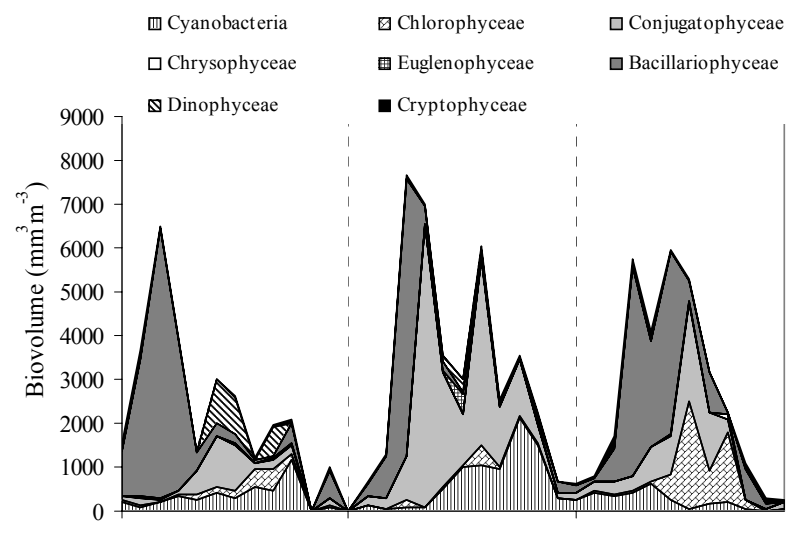

$\mathbf{A}$

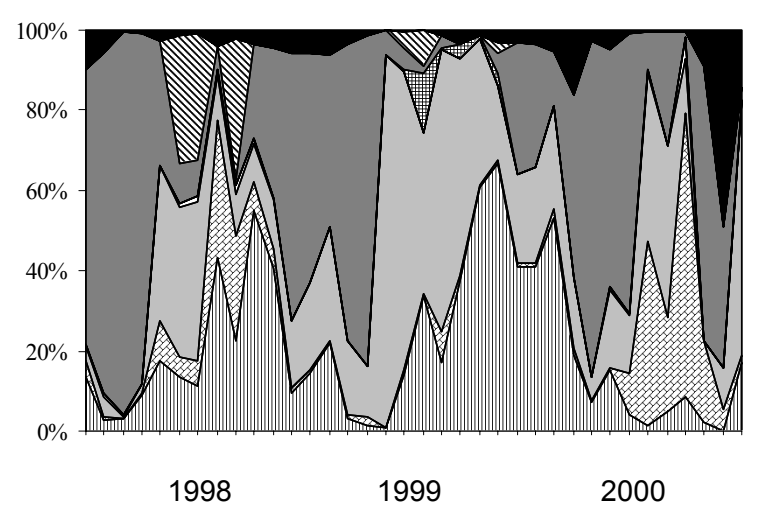

C

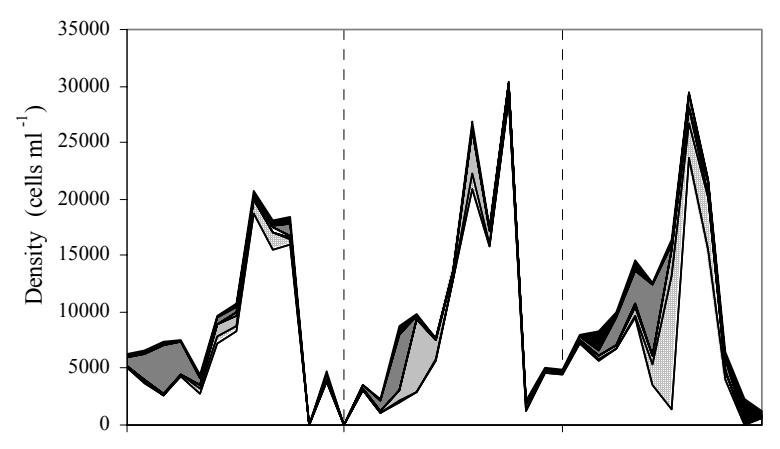

B

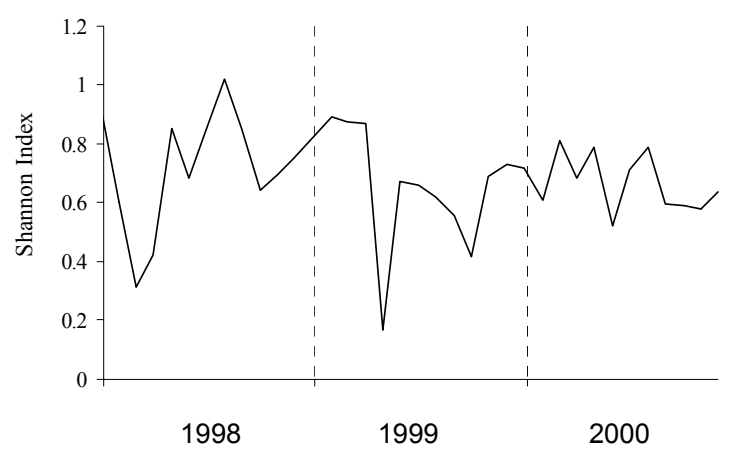

D

Fig. 6. Temporal variations of (A) biovolume and (B) density values subdivided by algal groups; (C) changes in the percent contribution of the phytoplankton groups to total biovolume in the $0-10 \mathrm{~m}$ layer and (D) temporal variations of diversity values.

spring), Conjugatophyceae (in spring and summer) and Cyanobacteria (late summer and autumn); Dinophyceae and Chlorophyceae were particularly important in 1998 and 2000 respectively. Mean annual total biovolumes in 1998, 1999 and 2000 were respectively 2629, 3469 and $2781 \mathrm{~mm}^{3} \mathrm{~m}^{-3}$.

The Shannon index seems to highlight a more marked variability in phytoplankton diversity in the two years 1998-1999 than in 2000 (Fig. 6D). Whereas in the first two years the index was between $c a$ 0.3-1.0 and $0.2-0.9$, in the third year the lower index values were observed in correspondence with the dominance of a single group or single systematic units, such as Bacillariophyceae in March 1998 (Aulacoseira islandica) and May 1999 (Fragilaria crotonensis), and Cyanobacteria in October 2000 (Planktothrix rubescens).

Following the criterion proposed by Ruggiu (1983), table 2 lists, in order of abundance, the species which contributed at least in one occasion to the formation of $80 \%$ of the total biovolume. Biovolume peaks and frequency of appearance, calculated over the whole three year period, are shown for each species. The seasonal evolution of the dominant species given in table 2 is reported in figures $7 \mathrm{a}$ and $7 \mathrm{~b}$.
The species appearing in almost all the samples (with frequency $>90 \%$ ) were Cyclotella comensis, Rhodomonas minuta and Planktothrix rubescens. The first two were never present with high biovolume values during the study period.

In terms of biovolume, the most abundant species in Lake Iseo were the diatoms. This group was represented by five species, which developed with biovolume peaks greater than $1000 \mathrm{~mm}^{3} \mathrm{~m}^{-3}$ (Aulacoseira islandica, Fragilaria crotonensis, Melosira varians, Asterionella formosa and Aulacoseira spp., mainly represented by $A$. granulata). In the other groups, the species with peaks exceeding $1000 \mathrm{~mm}^{3} \mathrm{~m}^{-3}$ were Mougeotia sp., Planktothrix rubescens, Sphaerocystis schroeteri and Coelastrum reticulatum (Tab. 2).

Among the cyanobacteria, apart from an isolated peak of Planktolyngbya limnetica recorded in 1999, Planktothrix rubescens reached an annual development around one order of magnitude greater than other taxa. The maximum development of this species in 1998 and 1999 was recorded in summer and autumn (Figs 7a and $6 \mathrm{~A}$ ); otherwise, its late summer and autumn development in 2000 was lower. The other cyanobacteria developed almost exclusively during late summer-early 
Tab. 2. Dominant phytoplankton taxa identified in Lake Iseo from 1998 to 2000. The table includes the species that, starting from the most abundant and at least in one occasion, have contributed to the $80 \%$ of the biovolumes of the identified taxa.

\begin{tabular}{|c|c|c|}
\hline & Max. biovolume & Frequency (\%) \\
\hline \multicolumn{3}{|l|}{ CYANOBACTERIA } \\
\hline Aphanotece clathrata & 95 & 35 \\
\hline Planktothrix rubescens & 2113 & 94 \\
\hline Chroococcus limneticus & 71 & 15 \\
\hline Planktolyngbya limnetica & 700 & 62 \\
\hline Gomphosphaeria lacustris & 148 & 12 \\
\hline Microcystis aeruginosa & 67 & 12 \\
\hline \multicolumn{3}{|l|}{ CHLOROPHYCEAE } \\
\hline Chlorella vulgaris & 309 & 18 \\
\hline Coelastrum reticulatum & 1417 & 20 \\
\hline Oocystis sp. & 380 & 15 \\
\hline Sphaerocystis schroeteri & 1485 & 59 \\
\hline Monoraphydium spp. & 101 & 41 \\
\hline Dictyosphaerium pulchellum & 502 & 12 \\
\hline \multicolumn{3}{|l|}{ CONJUGATOPHYCEAE } \\
\hline Mougeotia sp. & 6386 & 85 \\
\hline Closterium aciculare & 815 & 62 \\
\hline Staurastrum spp. & 800 & 11 \\
\hline \multicolumn{3}{|l|}{ CRYPTOPHYCEAE } \\
\hline Rhodomonas minuta & 153 & 94 \\
\hline Cryptomonas erosa & 197 & 79 \\
\hline \multicolumn{3}{|l|}{ BACILLARIOPHYCEAE } \\
\hline Aulacoseira islandica var. helv. & 5531 & 41 \\
\hline Aulacoseira spp. (mainly A. granulata) & 1139 & 15 \\
\hline Melosira varians & 2678 & 29 \\
\hline Cyclotella comensis & 179 & 91 \\
\hline Fragilaria crotonensis & 3979 & 73 \\
\hline Diatoma elongatum & 756 & 23 \\
\hline Asterionella formosa & 1956 & 62 \\
\hline \multicolumn{3}{|l|}{ DINOPHYCEAE } \\
\hline Ceratium hirundinella & 975 & 15 \\
\hline
\end{tabular}

autumn (Aphanothece clathrata, Gomphosphaeria lacustris, Chroococcus limneticus and Microcystis aeruginosa) or autumn (Planktolyngbya limnetica).

The green algae were dominated almost exclusively by Conjugatophyceae; the Chlorophyceae were represented by a rather diversified number of species belonging to the Chlorococcales, which developed almost exclusively during summer and early autumn (Fig. 7a). In the three study years, however, only a few species developed with regular cyclicity (Coelastrum reticulatum, Monoraphidium spp. and Sphaerocystis schroeteri), while others were recorded in significant biovolumes only in single years (Chlorella vulgaris, Oocystis sp. and Dictyosphaerium pulchellum). The presence of Conjugatophyceae characterised much of the annual development of the phytoplankton community (Fig. 6B). The filaments of Mougeotia sp. had their maximum development only in late spring and summer; the temporal trend of Closterium aciculare and Staurastrum spp. was characterised by a more irregular development, with maximum biovolumes in early or mid summer.

The dominant diatoms can be subdivided into three main types according to their seasonal development (Fig. 7b). The first group is the most numerous, and includes the species whose temporal development is strictly confined to late winter and spring (Aulacoseira islandica, A. granulata, Asterionella formosa and Melosira varians). The second group comprises species which, while having their maximum development in spring, can develop, sporadically and with smaller biovolumes, also in mid summer and/or autumn (Fragilaria crotonensis and Diatoma elongatum). Unlike the two former types, the small Cyclotella comensis has been found albeit with much lower biovolumes than other diatoms - in spring and summer.

The Cryptophyceae were characterised by a somewhat irregular development. In 1999 and 2000 Rhodomonas minuta had biovolume peaks in spring and autumn, with winter and summer minima (Fig. 7b); Cryptomonas erosa also seems to present a situation of the same type. The size of these two species suggests that their decrease in summer depends strongly on the development of herbivorous zooplankton. Dinophyceae, with Ceratium hirundinella, were recorded with high biovolumes only in summer 1998 and 1999 (Fig. 7b). 

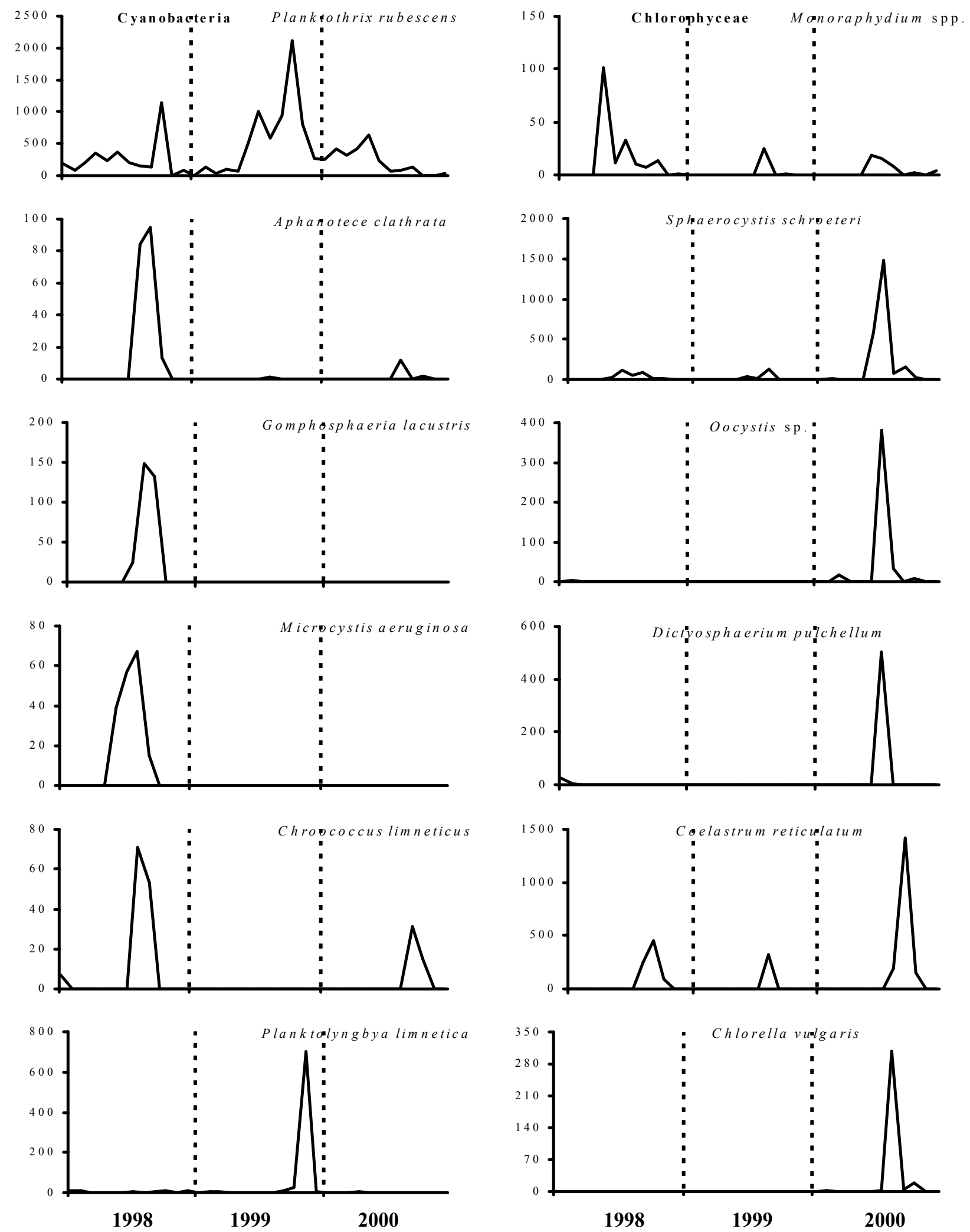

Fig. 7a. Temporal variations of biovolumes $\left(\mathrm{mm}^{3} \mathrm{~m}^{-3}\right)$ for the most abundant taxa (cf. table 2$)$ in the $0-10 \mathrm{~m}$ layer. 

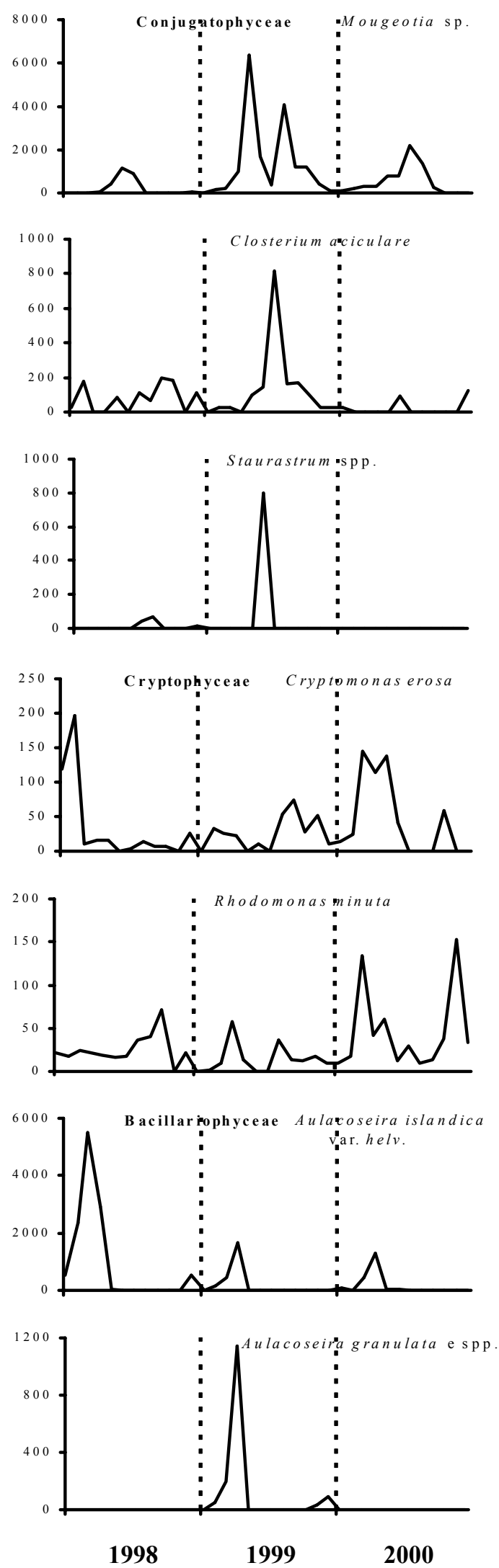
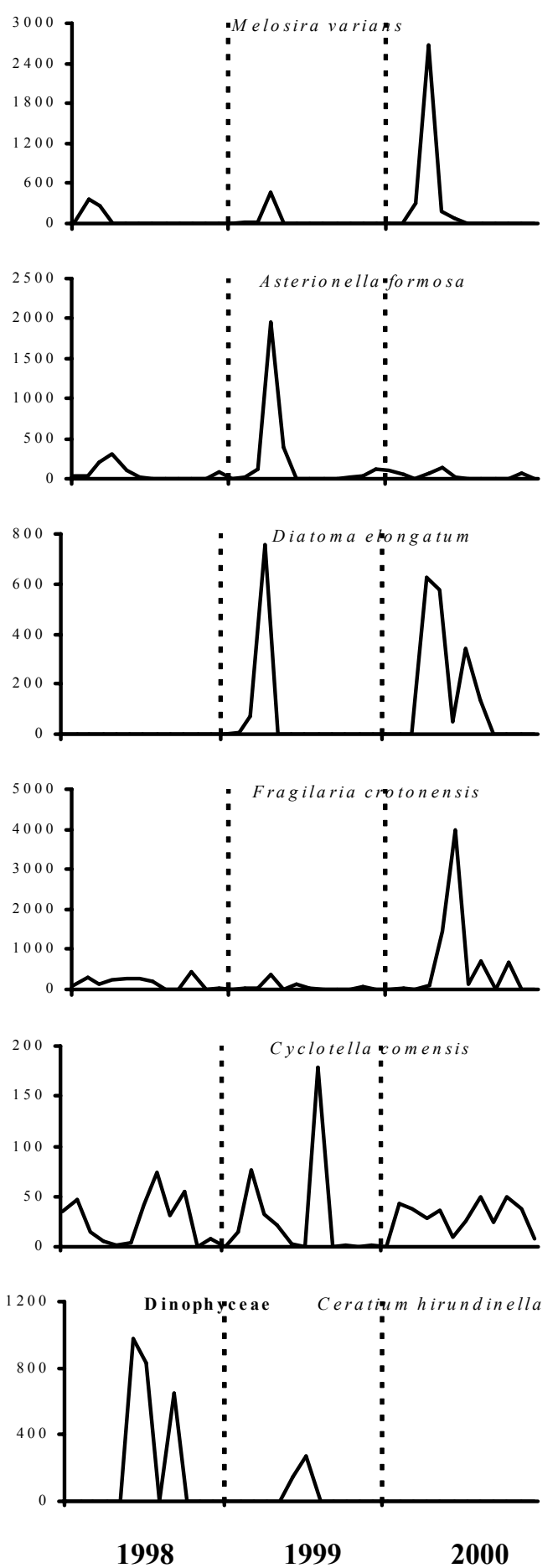

Fig. 7b. Temporal variations of biovolumes $\left(\mathrm{mm}^{3} \mathrm{~m}^{-3}\right)$ for the most abundant taxa (cf. table 2) in the 0-10 m layer. 


\section{DISCUSSION}

\subsection{Development of the phytoplankton community}

The temporal development of the algal biomass follows a fairly regular annual trend. Over the three years of the study, this had major consequences for the chemical characteristics of the water and for transparency (see sections 4.2., 4.3. and 4.5.). However, on the whole, the trend of chlorophyll- $a$ values, and to a lesser extent the trend of total biovolume, exhibit more or less marked phases of decrease in late spring, perhaps due to grazing by herbivorous zooplankton.

The seasonal development of phytoplankton groups in Lake Iseo showed common characteristics in the three study years. The main algal groups developed with a regular, cyclical seasonal succession, characterised in particular by the growth in late winter and spring of large colonial diatoms (pennate and centric), in late spring and summer of Conjugatophyceae (mostly Mougeotia sp.), and in autumn of cyanobacteria (mostly $P$. rubescens). Other algal groups showed striking growth in summer only in single years (e.g., Dinophyceae in 1998 and Chlorococcales in 2000).

The development of large diatoms in late winter and spring is favoured by the high turbulence associated with homothermy, and by the high concentrations of nutrients in the sampled layer. The decline of the large diatoms in the warmest months is due both to the progressive formation of a thermal gradient in the euphotic layer - which favours the sedimentation losses - and to the decrease of $\mathrm{Si}$ concentrations. In particular, the minimum Si concentrations reached in March and April (around $0.1 \mathrm{mg} \mathrm{l}^{-1}$ in 1998 and 2000, and $0.2 \mathrm{mg} \mathrm{l}^{-1}$ in 1999) may still support diatom growth, but to a level probably not sufficiently high to sustain a positive net balance in a progressively stabilised water column (cf. Salmaso 2000). However, the observations carried out in Lake Iseo show a different susceptibility of the various species to the increase in environmental stress deriving from the decrease of water turbulence and $\mathrm{Si}$ concentrations. In particular, and similarly to the situation observed in Lake Garda (Salmaso 2002) and Lago Maggiore (Morabito et al. 2002), the large filamentous centric diatoms (Aulacoseira and Melosira) appear to suffer particularly from the effects of the increased stability of the water column, whereas colonies of Fragilaria crotonensis may also develop in summer, albeit with lower biomasses. The only diatom showing a preferential development in summer is the small Cyclotella comensis. Its development is favoured by the small size (and thus by a lower sedimentation rate), and by the capacity for competing effectively for silica compared to the large pennate diatoms (Sommer 1987). On the other hand, compared to larger diatoms, its growth might be strongly limited by zooplankton grazing.

Mougeotia sp. filaments may constitute a major, and typical, phytoplankton component, not only in Lake Iseo, but also in the other large, deep subalpine lakes (cf. Ruggiu 1983). The development of this taxon is generally limited to late spring and summer. The success of Mougeotia is due to a complex of factors: it is a good competitor for phosphorus, resists predation by zooplankton, and suffers smaller losses than the large diatoms in thermally stratified environments (Sommer 1987). In particular, the large filaments of Mougeotia are an unsuitable food for the large herbivores which develop with their seasonal maxima in late spring and summer, such as the Daphnia hyalina-galeata complex and Copidodiaptomus steueri.

The filaments of Planktothrix rubescens are the most important components of the cyanobacteria. These organisms are present in lakes of different trophic states, although they usually show a greater development with increasing eutrophication (Watson et al. 1997). In Lake Iseo their development is particularly limited to late summer and autumn, as has been observed in other large lakes in the subalpine area (Walsby et al. 1998; Salmaso 2002). In particular, P. rubescens is a cyanobacterium which can thrive at light intensities which might be limiting for other types of algae (Reynolds 1984), and can therefore sustain a positive growth even in conditions of autumn thermal destratification and with an increase of the depth of the mixed layer in relation to the euphotic zone (decreasing values of the $\mathrm{Z}_{\mathrm{eu}} / \mathrm{Z}_{\text {mix }}$ ratios).

Again, over the last few years there have been a number of episodes of blooms of the cyanobacterium Anabaena lemmermannii. In particular, in August and September 1997, in conditions of high nutrient concentrations and with a water temperature above $23{ }^{\circ} \mathrm{C}$, a huge bloom of $A$. lemmermannii occurred along much of the shoreline in a band 10-15 $\mathrm{m}$ wide, along the shore of Monte Isola and in the marinas and harbours of the lake. The phenomenon was repeated to a lesser extent in August of the following year. In the deep subalpine lakes blooms of $A$. lemmermannii began to be documented only in Lake Garda at the end of the 1980s (Salmaso et al. 1994). These episodes, being made up of an accumulation of colonies in the top few centimetres of the water column (through vertical migration and accumulation along the shoreline) give a false impression of the abundance of this species in the phytoplankton community of the lake. In fact, routine counts representative of the pelagic layer between 0 and $10 \mathrm{~m}$ have always found Anabaena to be present in extremely small quantities.

\subsection{Trophic characteristics of Lake Iseo}

In deep lakes, including Lake Iseo, a key factor regulating the replenishment of nutrients in the epilimnetic layer is represented by the depth of the winter mixing. The importance of this factor emerged very clearly in a more detailed analysis of the causes behind the high phosphorus concentrations measured in 1999 and 2000 in the trophogenic layer. The last full circulation recorded in Lake Iseo was in 1981. From the mid 
Tab. 3. Trophic parameters used by OECD (1982) for the trophic characterisation of lakes and annual averages of phytoplankton biovolumes.

\begin{tabular}{lccc}
\hline & 1998 & 1999 & 2000 \\
\hline Total phosphorus, mean $(0-20 \mathrm{~m})\left(\mu \mathrm{g} \mathrm{P} \mathrm{l}^{-1}\right)$ & 11 & 21 & 21 \\
Total phosphorus, overturn $(0 \mathrm{~m}-$ bottom $)\left(\mu \mathrm{g} \mathrm{P}^{-1}\right)$ & 66 & 68 & 62 \\
Chlorophyll- $a$, mean $\left(\mu \mathrm{g} \mathrm{l}^{-1}\right)$ & 5.9 & 6.3 & 8.3 \\
Chlorophyll- $a$, maximum $\left(\mu \mathrm{g} \mathrm{l}^{-1}\right)$ & 14 & 15 & 32 \\
Secchi disk, mean $(\mathrm{m})$ & 5.2 & 5.3 & 4.9 \\
Secchi disk, minimum $(\mathrm{m})$ & 2.7 & 2.8 & 2.4 \\
Total biovolume, average $\left(\mathrm{mm}^{3} \mathrm{~m}^{-3}\right)$ & 2629 & 3469 & 2600 \\
\hline
\end{tabular}

1980s, the deep water underwent a progressive, stable isolation from the surface water, reaching conditions of anoxia in 1994 and 1995 (Garibaldi et al. 1997b; 1999). A detailed analysis of the physical and chemical profiles suggests that the 1999 and 2000 mixings in Lake Iseo involved a depth between 100 and $200 \mathrm{~m}$, contrasting with the much shallower mixing depth estimated for the previous year (between 50 and $100 \mathrm{~m}$ ). The greater depth of the mixed layer in 1999 and 2000 also determined a greater replenishment of phosphorus from the deep hypolimnion towards the surface layers. Salmaso et al. (2003) estimated that in 1998, during the limited overturn, the input of nutrients to the productive layers in Lake Iseo was below 10 t; in 1999 and 2000, during the greater extension of the overturn, this value increased to around 29 and $27 \mathrm{t}$, respectively; the importance of this replenishment is clear, if we consider that the external total load of TP was estimated at around 80-90 $\mathrm{t} \mathrm{y}^{-1}$.

Table 3 reports the trophic parameters used by the OECD (1982) for the trophic classification of lakes. The values indicate that Lake Iseo is in a condition between mesotrophy and eutrophy. However, the impact of the greater phosphorus supply to the surface layers in 1999 and 2000, and the shift towards more eutrophic conditions, are highlighted by the increase maximum chlorophyll- $a$ concentrations (in 2000 in particular), and by the decrease in mean transparency values.

At the level of phytoplankton community, the impact of the greater extension of the mixed layer did not produce the same consequences in 1999 and 2000. In the former year, the phytoplankton community was dominated by a strong development of Mougeotia sp., while the biovolume peaks in 2000 were determined by a stronger development of spring diatoms (Fragilaria crotonensis, Melosira varians and Diatoma elongatum).

\section{CONCLUSIONS}

The most typical algal groups in Lake Iseo are the large diatoms, conjugatophytes and cyanobacteria. Together, these groups contribute significantly to the aesthetic appearance and quality of the epilimnetic waters.

The large diatoms consist of two groups. The first group (Aulacoseira spp., Melosira varians and Asterionella formosa) comprises late winter and spring species adapted to high Si-concentrations and low water column stability. The second group is made up of spe- cies (Fragilaria crotonensis and Diatoma elongatum) which are able to develop from spring to mid summer and/or autumn, exhibiting an evident high capacity for withstanding low Si-concentrations and low water turbulence.

The dominance of Mougeotia sp. in spring and summer is favoured by its good competition for phosphorus and its resistance to sinking and grazing. The decrease of Mougeotia in summer occurs during the deepening of mixing and maximum nutrient depletion. In contrast, owing to their ability to survive at low light irradiances, the filaments of Planktothrix rubescens appear to be adapted to withstand the autumn conditions of vertical homogenisation and decreasing $\mathrm{Z}_{\mathrm{eu}} / \mathrm{Z}_{\text {mix }}$ ratios.

The species so far mentioned belong to groups which, in each of the three years of this study, alternated cyclically in the phytoplankton dominance of Lake Iseo. The temporal replacement of these three groups constitutes - in terms of biovolume - the main sequence of the annual phytoplankton succession in this large subalpine lake. On the other hand, this sequence can be integrated by the development of other algal classes, such as Dinophyceae and Chlorophyceae (almost exclusively represented by Chlorococcales).

The greater importance assumed by the various algal groups in each year may be due to changes in the meteoclimatic conditions during the whole vegetative season [as has been recorded for Lago Maggiore (Morabito 2001)], but also to the different pool of nutrients recycled from the deep to the surface layers as a result of late winter and spring circulation processes. However, the different development of dominant species in the two years (1999-2000) in which there was a greater extension of the mixed layer prevents the formulation of rules about the species able to develop with higher probabilities in response to episodes of higher fertilisation of the surface waters.

\section{REFERENCES}

Amoroso, C. 1984. Introduction pratique à la systematique des organismes des aux continentales françaises. 5. Crustaçes cladocères. Extrait du bolletin mensuel de la Société Limnéne de Lyon, $53^{\circ}$ anné, $n^{\circ} 5$. Association Française de Limnologie.

A.P.H.A., A.W.W.A., W.P.C.F. 1985. Standard Methods for the examination of water and wastewater. Am. Publ. Health Ass., Washington: 1268 pp. 
Barbieri, A. \& M. Simona. 1997. Evoluzione trofica recente del Lago di Lugano in relazione agli interventi di risanamento. Documenta Ist. ital. Idrobiol., 61: 73-91.

Bourrelly, P. 1966. Les Algues d'eau douce. 1. Les algues vertes. Boubée et Cie, Paris: 572 pp.

Bourrelly, P. 1968. Les Algues d'eau donce. 1. Les algues jaunes et rouges. Boubée et Cie, Paris: 517 pp.

Bourrelly, P. 1970. Les Algues d'eau douce. 1. Les algues bleues et rouges. Boubée et Cie, Paris: 606 pp.

Braioni, M.G. \& D. Gelmini. 1983. Rotiferi Monogononti (Rotaria: Monogononta). Guida per il riconoscimento delle specie animali delle acque interne italiane, 23. CNR AQ/1/200: 180 pp.

Dussart, B.H. 1969. Les Copepodes des eaux continentales. 2. Edition N. Boubée \& Cie, Paris : $292 \mathrm{pp}$

Einsle, U. 1996. Copepoda: Cyclopoida. Genera Cyclops, Megacyclops, Acanthocyclops. Guides to the Identification of the Microinvertebrates of the Continental Waters of the World, 10: $83 \mathrm{pp}$.

Garibaldi, L., M.C. Brizzio, G. Galanti, A. Varallo \& R. Mosello. 1997a. Idrochimica e fitoplancton del Lago d'Idro. Documenta Ist. ital. Idrobiol., 61: 153-172.

Garibaldi L., M.C. Brizzio, V. Mezzanotte, A. Varallo \& R. Mosello. 1995. The continuing evolution of Lake Iseo (N. Italy): the appearance of anoxia. Mem. Ist. Ital. Idrobiol., 53: 191-212.

Garibaldi, L., M.C. Brizzio, V. Mezzanotte, A. Varallo \& R. Mosello. 1997b. Evoluzione idrochimica e trofica del Lago d'Iseo. Documenta Ist. ital. Idrobiol., 61: 135-151.

Garibaldi, L., V. Mezzanotte, M.C. Brizzio, M. Rogora \& R. Mosello. 1999. The trophic evolution of Lake Iseo as related to its holomixis. J. Limnol., 58: 10-19.

Garibaldi, L., V. Mezzanotte, M.C. Brizzio, A. Varallo \& R. Mosello. 1998. Apporti di fosforo al Sebino. Confronto fra misure sperimentali e teoriche. Acqua Aria, 98/9: 105-110

Huber-Pestalozzi, G. 1938，1942，1955，1962，1968，1972, 1982, 1983. Das Phytoplankton des Süsswassers. Systematic und Biologie. Die Binnengewässer, 16 (8 voll.). E. Schweizerbart'sche Verlagsbuchhandlung, Stuttgart.

Hutchinson, G.E. 1957. A Treatise on Limnology. Vol. 1. Geography, Physics and Chemistry. John Wiley and Sons, Inc., New York; Chapman and Hall, Ltd., London: 1015 pp.

Lorenzen, C.J. 1967. Determination of chlorophyll and phaeopigments: spectrophotometric equations. Limnol. Oceanogr., 12: 343-346.

Lund, J.W.G., C. Kipling \& E.D. Le Cren. 1958. The Inverted Microscope method of estimating algal numbers and the statistical basis of estimations by counting. Hydrobiologia, 11: $143-170$.

Margaritora, F. 1983. Cladoceri (Crustacea: Cladocera). Guide per il riconoscimento delle specie animali delle acque interne italiane, 22. CNR AQ/1/197: $169 \mathrm{pp}$.

Morabito, G. 2001. Relationships between phytoplankton dynamics in Lake Maggiore and local climate in the period 1978-'98. Atti dell'Associazione Italiana di Oceanologia e Limnologia, 14: 147-156.

Morabito, G., D. Ruggiu \& P. Panzani. 2002. Recent dynamics (1995-1999) of the phytoplankton assemblages in Lago Maggiore as a basic tool for defining association patterns in the Italian deep lakes. J. Limnol., 61(1): 129-145.
Mosello, R. \& G. Giussani (Eds). 1997. Evoluzione recente della qualità selle acque dei laghi profondi sudalpini. Documenta Ist. ital. Idrobiol., 61: $230 \mathrm{pp}$.

Mosello, R. \& N. Salmaso. 2000. Cooperazione per lo studio della qualità delle acque dei laghi profondi sudalpini (QuAlps): obiettivi e primi risultati. Atti della Giornata di Studio: I Laghi come Risorsa per lo Sviluppo. Milano, 16 ottobre 1998. Politecnico di Milano, Consiglio Regionale della Lombardia, CNR-III Pallanza e Associazione ex Consiglieri Regionali della Lombardia: 39-50.

OECD. 1982. Eutrophication of waters. Monitoring, assessment and control. OECD, Paris : $154 \mathrm{pp}$.

Reddy, Y.R. 1994. Copepoda : Calanoida : Diaptomidae. Guide to the identification of the Microinvertebrates of the Continental of the World, 5: $220 \mathrm{pp}$.

Reynolds, C.S. 1984. The ecology of freshwater phytoplankton. Cambridge University Press, Cambridge, $384 \mathrm{pp}$.

Rodier, J. 1984. L'analyse de l'eau. Dunod, Paris: 1365 pp.

Rott, E. 1981. Some results from phytoplankton counting intercalibrations. Schweiz. Z. Hydrol., 43: 34-62.

Ruggiu, D. 1983. Caratteristiche e comportamento del fitoplancton nei laghi profondi sudalpini. In W. Ambrosetti, L. Barbanti, R. Mosello, A. Rolla \& D. Ruggiu (Eds), Mescolamento, caratteristiche chimiche, fitoplancton e situazione trofica nei laghi profondi sudalpini. C.N.R.P.F. Promozione della Qualità dell'Ambiente, AQ/2/20: 105-143.

Ruggiu, D. 2002. Phytoplankton in deep Italian lakes: introductory remarks. J. Limnol., 61(1): 93-94.

Ruttner-Kolisko, A. 1974. Plankton Rotifers, Biology and Taxonomy. Die Binnengewässer, 16/1 (Suppl.): 146 pp.

Salmaso, N. 2000. Factors affecting the seasonality and distribution of cyanobacteria and chlorophytes: a case study from the large lakes south of the Alps, with special reference to Lake Garda. Hydrobiologia, 438: 43-63.

Salmaso, N. 2002. Ecological patterns of phytoplankton assemblages in Lake Garda: seasonal, spatial and historical features. J. Limnol., 61: 95-115.

Salmaso, N., F. Cavolo \& P. Cordella. 1994. Fioriture di Anabaena e Microcystis nel Lago di Garda. Eventi rilevati e caratterizzazione dei periodi di sviluppo. Acqua Aria, $1(1): 17-28$.

Salmaso, N., R. Mosello, L. Garibaldi, F. Decet, M.C. Brizzio \& P. Cordella. 2003. Vertical mixing as a determinant of trophic status in deep lakes: a case study from two lakes south of the Alps (Lake Garda and Lake Iseo). J. Limnol., 62 (Suppl. 1): 33-41.

Sommer, U. 1987. Factors controlling the seasonal variation in phytoplankton species composition. A case study for a deep, nutrient rich lake. Prog. Phyc. Res., 5: 123178.

Valderrama, J.C. 1981. The simultaneous analysis of total nitrogen and total phosphorus in natural waters. Mar. Chem., 10: 109-122.

Walsby, A.E., A. Avery \& F. Schanz. 1998. The critical pressures of gas vesicles in Planktothrix rubescens in relation to the depth of winter mixing in Lake Zurich, Switzerland. J. Plankton Res., 20: 1357-1375.

Watson, S.B., E. McCauley \& J.A. Downing. 1997. Patterns in phytoplankton taxonomic composition across temperate lakes of differing nutrient status. Limnol. Oceanogr., 42: 487-495. 